\title{
ホットパックの乾熱法と湿熱法の違いが 筋硬度に及ぼす効果
}

\author{
Effects of Wet and Dry Heatpacks on Muscle Stiffness
}

\author{
古後 晴基1） 村田 伸 ${ }^{2}$ ～村田 潤3） 仲村 匡平4)
}

HARUKI KOGO, RPT, MS ${ }^{1)}$, SHIN MURATA, RPT, PhD $^{2)}$, JUn MURATA, OTR, PhD ${ }^{3)}$, KoUHEI NAKAMURA, RPT ${ }^{4}$

1) Department of Physical Therapy, Kurume Rehabilitation Institute: 1541 Mizuhara, Hirokawa-town, Yame-gun, Fukuoka 8340102, Japan. TEL +81 0943-32-7700

2) Faculty of Rehabilitation Science, Nishikyushu University

3) Department of Health Sciences, Graduate School of Biomedical Sciences, Nagasaki University

4) Department of Physical Therapy, Wajiro Rehabilitation Institute

Rigakuryoho Kagaku 25(4): 631-634, 2010. Submitted Feb. 25, 2010. Accepted Apr. 6, 2010.

ABSTRACT: [Purpose] In this study, we investigated and compared the effects on muscle stiffness of 'dry' and 'wet' heatpack treatments. [Subjects] Both legs of 10 healthy adults ( 7 men, 3 women, average age $22.3 \pm 6.8)$ were the subjects. [Method] Heatpacks were applied to the back of the lower thighs for 20 minutes with subjects lying in the prone position. For the wet treatment, the heatpack was wrapped in 8 layers of cotton towels, and for the dry treatment, in 3 layers of cotton towels after wrapping in a vinyl bag. The stiffness of the medial head of the gastrocnemius muscle was measured before and after the heatpack treatments. [Results] Both wet and dry heatpack treatments significantly reduced muscle stiffness compared to pretreatment. There was also a significant difference between the two treatments, with the wet treatment reducing muscle stiffness significantly more than the dry treatment. [Conclusion] The results suggests heatpacks are an effective treatment for reducing muscle stiffness, especially the effect of the wet treatment which was greater than that of the dry treatment.

Key words: thermotherapy, steam-heating, muscle stiffness

要旨：〔目的〕本研究は, 乾熱法と湿熱法でホットパック（以下HP）施行後の筋硬度の変化に及ぼす効果を比較検 討した。〔対象〕健常成人 10 名（男性 7 名, 女性 3 名, 平均年齢 $22.3 \pm 6.8$ 歳）の両下肢（20脚）を対象とした。〔方 法）被験者は腹臥位で，下腿部後面に直接HPを 20 分間施行した。湿熱法ではパックを直接コットンタオル（8層） で巻き, 乾熱法ではパックをビニール袋で包んだ後, コットンタオル（3層）で巻いてHPを施行した。HP施行前, 乾熱法および湿熱法 HP 施行後の腓腹筋内側頭の筋硬度を比較した。〔結果〕HP 施行前の筋硬度に比べ, 湿熱法お よび乾熱法による HP 施行後の筋硬度はともに有意に低下した。ただし, 湿熱法と乾熱法後の筋硬度にも有意差が 認められ，湿熱法の方が乾熱法より有意に低下した。〔結語〕HPは筋硬度を低下させる手段として有効であり，と くにその効果は湿熱法の方が乾熱法より高いことが示唆された。

キーワード : 温熱療法, 湿熱法, 筋硬度

1) 久留米リハビリテーション学院＼cjkstart理学療法学科：福岡県八女郡広川町水原1541番地（テ834-0102）TEL 0943-32-7700

2)西九州大学 リハビリテーション学部

3) 長崎大学大学院 医歯薬学研究科

4)和白リハビリテーション学院 理学療法学科

受付日 2010年2月25日＼cjkstart受理日２010年4月6日 


\section{I. 緒 言}

温熱による局所反応として，代謝機能の克進，末梢 血管拡張による血流量の増加, 神経伝導速度の増加, 軟部組織成分であるコラーゲン線維の伸張性増大, 生 体の免疫機能の立進がある1)。近年では, 温熱療法によ り骨格筋内の熱ショック蛋白Heat shock protein72(Hsp72) の発現が増加することが確認され，さらにラット骨格 筋の廃用性筋萎縮の発生や進行が軽減されることが報 告されている2-4)。

熱の伝達は, その方法によって伝導, 対流, 輻射, 変 (転) 換の四つに分けられる5)。このうち, 伝導とは対 象となる物質が熱源に直接触れることによって起こる 熱の移動である6)。伝導熱を利用した温熱療法の代表 的なものとしてホットパック（以下HP）があり，湿熱 法と乾熱法に大別される。湿熱法には, シリカゲルを 厚手の木綿袋に詰めたものを恒温浴（ハイドロコレー タ）に浸した後，コットンタオルで包んで利用する HP があり，一般に普及している。水分を含んだシリカゲ ルはゲル状になることで，水分子の対流を防止するこ とができることから比熱が高く, シリカゲルを利用し たものは熱容量が大きい7)。しかし, 湿熱法はいくつか の欠点を持つ。まず，衣服を湿潤させるため，不快で あると伴に熱傷の危険性が高まる。また，衣服の湿気 が蒸発することにより, HP 施行後に急激に皮膚温を下 降させることになる。よって, 衣服を湿潤させないた めには, 患部に HP を直接あてて加温する必要がある。 また, 準備の面から見ると湿熱法はコットンタオルを 乾かすための時間を要すため, 多くのコットンタオル が必要となる。これらの理由から, パックをビニール で包んだ後，コットンタオルで巻いて衣服の上から行 う乾熱法HPとして使用されることが多い。

温熱療法の効果に関する先行研究では, 皮膚表面温 度 6,8 ) や皮膚血流量9,10) の変化, ならびに筋腱の張力と 長さ11)や神経伝導速度 ${ }^{12)}$ の変化に関寸る研究などがあ る。筋腱の張力変化において, 筋腱の張力は温熱療法 後, 有意に低下寸ることが報告されている11)。しかし, 筋硬度の変化に関する研究はほとんどない。矢吹らは, 前屈位と腹臥位の腰部脊柱起立筋の筋硬度をHP施行前 後で比較している。彼らによると, 前屈位ではHP施行 後は有意に筋硬度が低下したが，腹臥位では有意差が なかったと述べている13)。そこで我々は, 安静肢位(腹 卧位）における筋硬度が，HPの施行後に有意に低下寸 るかどうか明らかにすることを目的とした。また，先 行研究では, 筋張力や筋硬度を乾熱法と湿熱法とで比
較した報告がないため, 乾熱法と比べ湿熱法が筋硬度 を低下させる効果があることを明らかにし，臨床で普 及させる目的で研究を行った。

\section{II. 対象と方法}

\section{1. 対象}

被験者は, 健常成人 10 名 20 脚（男性 7 名, 女性 3 名) であり, 平均年齢は $22.3 \pm 6.8$ 歳, 平均身長は $163.7 \pm 7.3$ $\mathrm{cm}$, 平均体重は $61.2 \pm 11.5 \mathrm{~kg}$ であった。なお, 被験者 には研究の趣旨と内容, 得られたデータは研究目的以 外には使用しないこと, および個人情報の取り扱いに は十分に配慮することを説明し, 自らの意思で参加し てもらった。

\section{2. 方法}

室温を $25^{\circ} \mathrm{C}$ 前後に保った実験室で, 被験者を治療用 ベッドに腹卧位にし, 下腿部後面に直接HPを 20 分間施 行した。パックは, ハイドロコレータ (酒井医療社製) 内の水温を $80{ }^{\circ} \mathrm{C}$ に保ち 1 時間以上浸したものを使用し た。HPを湿熱法として使用する場合は，パックを直接 コットンタオルで巻き（身体にあてる側を 8 層），反対 側は熱が放射しないようコットンタオルを何層にも重 衩た。また，乾熱法として使用する場合は，パックを ビニール袋で包んだ後，コットンタオルで巻き（身体 にあてる側を 3 層)，湿熱法と同様に反対側は熱が放射 しないようコットンタオルを何層にも重礼た。被験者 の左右の下腿部のうち片側が湿熱, もう一方が乾熱と なるよう設定したが，その割り付けは無作為とし，さ らに被験者にはHPの種類を伝えないよう留意した。な お, $\mathrm{HP}$ 施行直前の表面温度を赤外線温度計（SATO 社 製PC-8400 II）で測定し，HP 表面温度が $40 \sim 45{ }^{\circ} \mathrm{C} に$ なったのを確認して実験を開始した。

筋硬度の測定は，TRY-ALL 社製 NEUTONE TDM-N1 （DX）を使用して，HP施行前後に行った。被験者を腹 臥位で筋収縮を起こさないようリラックスさせ，筋硬 度計を腓腹筋内側頭の最大膨大部に垂直にあて, 筋硬 度を3 回測定してその平均値を用いて分析した。

統計解析は，HP 施行前の筋硬度を基準（100\%）と して, 湿熱法後および乾熱法後の筋硬度の変化（百分 率で表記）について分析した。施行前，湿熱法後，乾 熱法後における 3 回の繰り返しデータの変化率を反復 測定分散分析ならびにSheffeの多重比較検定を行った。 なお, 湿熱法と乾熱法における HP 施行直前の表面温度 の比較については, 対応のないt検定を採用した。また, 
表1 ホットパック施行前後の筋硬度の変化率

\begin{tabular}{ccccc}
\hline & 施行前 & 乾熱法後 & 湿熱法後 & 分散比 \\
\hline 筋硬度 & 100 & $\left.94.2 \pm 4.9^{* * a}\right)$ & $89.9 \pm 3.8^{* * b)}$ & $21.0^{* *}$ \\
\hline
\end{tabular}

平均土標準偏差, 反復測定分散分析, 多重比較検定 Scheffe 法 $* * \mathrm{p}<0.01$

a): 施行前と乾熱法後に有意差有り

b) 施行前および乾熱法後と湿熱法後に有意差有り

それぞれの検定の有意水準は5\%未満とし,データは平 均值土標準偏差で示した。

\section{III. 結 果}

湿熱法と乾熱法における HP 施行直前の HP 表面温度 は, 湿熱法HP $の$ 表面が平均 $42.6 \pm 2.6{ }^{\circ} \mathrm{C}$, 乾熱法HP 表面が平均 $42.8 \pm 2.6{ }^{\circ} \mathrm{C}$ であり, 2 群間に有意差は認め られなかった。

筋硬度の群間比較について, 群間に有意差（F=21.0, $\mathrm{p}<0.01)$ が認められ, 多重比較により HP 施行前の筋硬 度に比べ, 湿熱法後および乾熱法後の筋硬度はともに 有意 $(\mathrm{p}<0.01)$ に低下した。さらに, 湿熱法後と乾熱法 後の筋硬度にも有意差 $(\mathrm{p}<0.01)$ が認められ, 湿熱法後 の筋硬度が乾熱法後の筋硬度より有意に低下した(表1)。

\section{IV. 考 察}

今回, HP 施行前と比較して HP 施行後は, 乾熱法お よび湿熱法ともに筋硬度が有意に低下した。ただし， 乾熱法と湿熱法の効果にも有意差が認められ, 乾熱法 に比べ湿熱法の方が有意に筋硬度を低下させた。

筋腱の結合組織はコラーゲン線維であり, 加温する ことにより伸張性が高まることが明らかにされてい る1)。Lehmann らは, $25{ }^{\circ} \mathrm{C} と 45{ }^{\circ} \mathrm{C} の$ 温水に筋腱組織を 浸し, $73 \mathrm{~g}$ の力で引つ張った際の筋腱の長さの変化を 実験している。彼らは $25{ }^{\circ} \mathrm{C}$ 温水では筋腱の長さに変 化は見られなかったが, $45{ }^{\circ} \mathrm{C}$ 温水では長さが増加し たと報告している11)。つまり，45 ${ }^{\circ} \mathrm{C}$ の温熱は筋腱の伸 張性に影響を及ぼすことを示唆している。本研究にお いても, HPの表面温度を $45^{\circ} \mathrm{C}$ 弱に設定したことによ り筋腱の伸張性が高まり, 筋硬度が有意に低下したも のと推察された。

篠原らはHPをバスタオルで 8 10枚重ねにして行う 湿熱法と, HPをビニールで包んだ後にバスタオルで重 ねる乾熱法で, バスタオルの温度変化を時間ごとに計
測し比較している ${ }^{14)}$ 。外層温度は乾熱法の場合, 時間 の経過とともに高い值となったが, 湿熱法は初めから 高い值を示しその温度を維持したと報告している。ま た，この結果は熱伝導性が湿熱法の方が良いためだと 述べている。これは, 空気および綿の熱伝導率はそれ ぞれ $0.0092,0.0796 \mathrm{~W} / \mathrm{m} ・{ }^{\circ} \mathrm{C}$ あるあに対し，蒸気では

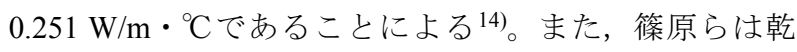
熱法でバスタオル 3 枚の時の皮膚表面温度が, 湿熱法 でバスタオル 10 枚の時の皮膚表面温度に相当したとも 述べている ${ }^{14)}$ 。彼らの研究では, 乾熱法を施行した場 合の皮膚表面温度は徐々に上昇するのに対し, 湿熱法 を施行した場合の皮膚表面温度は急激に上昇している。 その後, HP施行 20 分経過時に皮膚表面温度がほぼ同温 度となり, 時間経過とともに, 湿熱法の方が逆に表面 温度がより下降している。これは熱伝導率の違いと浸 潤した水蒸気が気化する時に熱を奪われたことによる。 本研究では, 湿熱法による水蒸気が気化する影響をで きるだけ除外できるようにHPの施行時間を 20 分間と した。このことが, 乾熱法よりも湿熱法の方が有意に 筋硬度を低下させた理由かもしれない。

HP の伝導熱は, 生体に適用しても深達度は皮下 1 $2 \mathrm{~cm}$ であり ${ }^{15)}$, 皮膚や皮下組織の温度上昇をもたらす が, 筋腱といった比較的深部の軟部組織の温度を上昇 させるには不適切な手段と言われている16)。しかし， 今回の結果では, HPは筋硬度を低下させる手段として 有効であり，とくにその効果は湿熱法の方が乾熱法よ り高いことが示唆された。これらの知見から, 臨床に おいてHPをストレッチの前処置など, 筫腱の伸張性を 求めるアプローチに使用する場合, 湿熱法の方が効果 的であることが示された。

\section{引用文献}

1) 細田多穂（監）: 物理療法学テキスト. 木村貞治, 沖田 実, Goh Ah Cheng (編), 南江堂, 東京, 2008, pp33-41.

2) Naito H, Powers SK, Demirel HA, et al.: Heat stress attenuates skeletal muscle atrophy in hindlimb-unweighted rats. J Appl Physiol, 2000, 88: 359-363.

3) 沖田 実, 中居和代, 片岡英樹 - 他 : 廃用性筋萎縮の予防と しての温熱負荷の影響に関する研究. 理学療法学, 2004, 31: 63-69.

4) 坂口 顕, 沖 貞明, 金井秀作・他 : 廃用性筋萎縮予防とし ての温熱療法の効果. 理学療法科学, 2008, 23: 23-27.

5) 上田 敏, 千野直一, 大川嗣雄 (編) : リハビリテーション 基礎医学. 医学書院, 東京, 2001, pp5-12,pp377-381.

6) 岡崎大資, 鶴見隆正, 川村博文・他 : 温熱療法の有効性とリ スク管理. PTジャーナル，2006, 40: 117-124.

7) 松澤 正, 目黒 力, 田子利法・他 : ホットパック療法にお 
ける治療時間の検討. 群馬パース大学紀要, 2007, 4: 427-433.

8) 上川浩樹, 寺田和彦, 中川 浩・他 : ホットパックの使用方 法が表面温度にあたえる影響. 九州理学療法士・作業療法士 合同学会誌, 2007, p156.

9) Kellogg DL Jr: In vivo mechanisms of cutaneous vasodilation and vasoconstriction in humans during thermoregulatory challenges. $\mathrm{J}$ Appl Physiol, 2006, 100: 1709-1718.

10) Charkoudian N: Skin blood flow in adult human thermoregulation: how it works, when it does not, and why. Mayo Clin Proc, 2003, 78: 603-612.

11) Lehmann JF, Masock AJ, Warren CG, et al.: Effect of therapeutic temperatures on tendon extensibility. Arch Phys Med Rehabil, 1970, 51: 481-487.
12) Todnem $T$, Knudsen $G$, Riise $T$, et al.: The non-linear relationship between nerve conduction velocity and skin temperature. J Neurol Neurosurg Psychiatry, 1989, 52: 497-501.

13) 矢吹省司, 菊地臣一, 添田幸英・他 : 腰痛症に対寸る理学療 法一理論と実際一。日本腰痛会誌, 2005, 11: 97-101.

14) 篠原英記, 市橋則明, 吉田正樹・他：ホットパックの適切な 使用時間について. 理学療法学, 1989, 16: 351-354.

15) 高杉紳一郎, 岩本幸英: 腰痛の物理療法. MB Med Reha, 2008, 98: $25-31$.

16) 出口清喜, 椿 淳裕, 由久保弘明・他 : 軟部組織（靭帯を含 む）修復における物理療法の有効性. 理学療法, 2004, 21: 1358-1365. 